\title{
Legal Opportunities for Public Participation in Forest Management in the Republic of Korea
}

\author{
Mi Sun Park ${ }^{1, *}$ and Hyowon Lee ${ }^{2}$ \\ 1 Department of Environmental Planning, College of Life and Environmental Sciences, Konkuk University, \\ \#225, 120 Neungdong-ro, Gwangjin-gu, Seoul 05029, Korea \\ 2 School of Law, Seoul National University, 1 Gwanakro, Gwanakgu, Seoul 08826, Korea; leewon35@snu.ac.kr \\ * Correspondence: mpark@konkuk.ac.kr; Tel.: +82-2-450-3739
}

Academic Editor: Vincenzo Torretta

Received: 25 January 2016; Accepted: 11 April 2016; Published: 14 April 2016

\begin{abstract}
Participation by multiple actors has been emphasized in managing state forests to meet various demands on forests within a global society. Public participation was also suggested as an approach to sustainable forest management. This paper aims to investigate the legal opportunities of public participation in managing state forests in the case of the Republic of Korea (ROK). Relevant legal and policy documents were selected for content analysis and were analyzed with the levels of participation. Litigation regarding state forest conflicts was analyzed. The ROK legal system includes multiple levels of participation in managing state forests: information sharing, consultation, collaborative decision-making, and implementation. The research results indicate that various stakeholders need legal opportunities to participate in the formation and implementation of policies for the management of state forests. Regulatory enforcement is required for guaranteeing environmental rights-access to information, participation in decision-making, and standing in court. Based on research results, this paper provides us with legal insights on promoting public participation in managing state forests.
\end{abstract}

Keywords: public participation; forest management; state forests; environmental rights

\section{Introduction}

Information disclosure and public participation has been emphasized in environmental decision-making within a global society. The United Nations Conference on Environment and Development (UNCED), held in Rio de Janeiro in 1992, highlighted the importance of public participation in Principles 10 and 22 of the Rio Declaration [1]. Public participation was also encouraged in Agenda 21 [2]. One of the most important and recent efforts to ensure that states guarantee opportunities for the public to have a voice in environmental decision-making is the Convention on Access to Information, Public Participation in Decision-making and Access to Justice in Environmental Matters [3] at the Aarhus Ministerial Conference, here abbreviated as the Aarhus Convention. It was signed by 47 parties—46 states in Europe and Central Asia and the European Union. The Aarhus Convention is formed by three pillars: access to information, public participation and access to justice in governmental decision-making processes on matters concerning the local, national, and transboundary environment [4]. It is the first multinational environmental agreement that focuses on the obligations of nations to their citizens and non-governmental organizations [5]. The environmental rights highlighted by the Aarhus Convention helped secure more transparent and accountable regulatory process of environmental decision-making [6].

Information disclosure and environmental rights of the public concern the forestry sector. Public participation has been regarded as an approach to sustainable forest management (SFM) [7-9]. The Forest Principles [10], as a non-legally binding agreement on forests signed by many countries at the 
UNCED, indicate that the provision of timely, reliable, and accurate information on forests and forest ecosystems is essential for public understanding and informed decision-making and should be ensured (Article 2(c)). They recommend that governments should promote and provide opportunities for the participation of interested parties in developing and implementing national forest policies (Article 2(d)). Public participation increases public awareness of forests and forestry, enhances social acceptance of sustainable forest management, and shares costs and benefits in a fair and equitable way [11] (p. 7). It can contribute to the reduction of forest conflicts and nurture a positive relationship among them [9]. Participatory forest management has become a widely accepted solution to forestry problems.

Many studies emphasize meaningful participation in forest management. Forest management, including public participation, is presented as community-based forest management or community forest management [12,13], joint forest management [14,15], and participatory forest management [16-18]. In many studies, the importance of public participation in forest management planning has been emphasized $[8,9,19]$. Regulatory instruments can support public participation in forest management for guaranteeing three forest rights, including access to information, public participation in decision-making, and access to justice in forest matters. Among the studies on the legal framework of participatory forest management, most research has focused on community-based rights and tenure $[20,21]$. This study attempts to examine the legal opportunities for public participation in the management of state forests in the case of the Republic of Korea (ROK) considering the level of public participation and the Aarhus Convention environmental rights. This study can help to characterize the use of regulatory enforcement and compliance to promote public participation in managing state forests.

\section{Public Participation in Forest Decision-Making}

Over the last several decades, public participation has emerged as a key component of forest management and policy decision-making [22]. Public participation is inclusive with respect to interests, voluntary, may complement the existing legal and institutional framework, fair and transparent to all participants, based on participants acting in good faith and does not guarantee the outcome [11] (p. 5). Cox [23] defines public participation as the ability of individual citizens and groups to influence decisions through three rights: (a) the right to know or access to information; (b) the right for public comment, and; (c) the right of standing in courts. The importance of these rights was already confirmed by the Aarhus Convention. These rights have been emphasized in the forestry sector. Access to relevant forest information is crucial in the process of forest decision-making. Individuals should have access to information on forest conditions or governmental actions that affect forests. The better the information, the more easily the stakeholder can choose the optimum forestry measures to promote his or her self-interests [24] (p. 151). In particular, free, prior, and informed consent (FPIC) is regarded as a means for indigenous people and local communities to shape the direction and outcomes of forest management activities including REDD+ (reducing emissions from deforestation and forest degradation and enhancing conservation, the sustainable management of forests and forest carbon stocks) [25]. The right to know and access to information reflect the principle of transparency or the openness of governmental actions to public scrutiny [23]. Transparency is essential to successful public participation [11] (p. 5).

The right to comment to the agency that is responsible for a decision should be guaranteed. Public comment typically takes the form of in-person, spoken testimony at public hearings, exchanges of views at open meetings, written communications to agencies, and participation on citizen advisory committees [23]. Public participatory processes refer to formal procedures of public consultation about specific forest practices and projects [11] (p. 8). Consultation requires an in-depth discussion between the key stakeholders to be conducted by means of appropriate timing and methods [26]. The right to public comment reflects the principle of direct participation in democratic decisions and governance $[23,27]$. Public comments can be submitted to decision-makers, who are responsible for the final decision. 
The third method for public participation in forest decision-making is the right of standing in courts. This right is based on the presumption that an individual having a sufficient interest in a matter may stand before a legal authority to speak and seek protection of that interest in court [23]. In actuality, cases of the United States courts of appeals include national forest litigation. Among 119 published cases involving the management of national forests from 1970 to 2001, environmental interests were the plaintiff (the party suing the Forest Service) in 103 (86.6\%) of the national forest management cases and the appellants (the party appealing the district court's decision) in 85 cases (71.4\%) [28]. The forest litigation activities reflect accountability as one of the principles of good forest governance [29]. Accountability implies that some actors have the right to hold other actors to a set of standards, to judge whether they have fulfilled their responsibilities in light of these standards, and to impose sanctions if they determine that these responsibilities have not been met [30] (p. 29). It means that actors possess the authority to demand redress for wrongdoings or harmful behavior [31]. Citizens could invoke their right of standing by filing citizen lawsuits [23].

Participation may occur at various stages of the decision-making and policy process. It can be divided into several levels in terms of power and roles by the different stakeholders. Arnstein [32] differentiated the amount and depth of citizen participation through an eight-rung ladder: manipulation; therapy; informing; consultation; placation; partnership; delegated power; and citizen control. The eight levels are grouped into three steps: non-participation, tokenism and citizen power in the process of decision-making. Brua-Garcia and Marey-Perez [9] proposed five levels of public participation in forest planning: information; consultation; decision; performance; and self-organization. The level of information is unidirectional information flow without public participation. At the level of consultation, citizens review and comment on the planning proposals. At the level of decision, citizens influence decisions as partners of authorities. At the level of performance, citizens are dominant in controlling decision-making. At the self-organization level, citizens fully control decision-making independently from the authorities. According to the level of involvement and the amount of influence should participants have on the decision, Maier et al. [33] divided public participation into four categories: information (little influence); consultation (some influence); co-decision-making (much influence); and negotiated agreement (highest level of influence). Three environmental rights - the right to know, the right of public comment, and the right of standing in court-can be interpreted as linking with level of participation and three key dimensions of forest governance: transparency, participation, and accountability, as highlighted by Secco et al. [27] (Table 1).

Table 1. Environmental rights, participation levels and key dimensions of governance.

\begin{tabular}{ccc}
\hline Environmental Right & Level of Participation & Key Dimension of Governance \\
\hline Right to know & Information sharing & Transparency \\
\hline Right of public comment & $\begin{array}{c}\text { Consultation } \\
\text { Collaborative decision-making } \\
\text { Implementation }\end{array}$ & Direct participation \\
\hline Right of standing in court & Implementation (Litigation) & Accountability \\
\hline
\end{tabular}

\section{Context of the Republic of Korea}

The total land area of South Korea is approximately 10,028,395 ha [34] (p. 22). The forest area is approximately $6,408,069$ ha, nearly $63.7 \%$ of the total land. South Korean forests consist of national (24\%), local government-owned forests (8\%), and private forests (68\%) [34] (p. 42). According to Article 6 of the Framework Act on Forestry, the state and local governments shall endeavor to cultivate and protect the forests by establishing long-term goals and directions such that various dimensions of forests, such as preservation of the land and the environment and the supply of forest products, may be fully exhibited. According to Article 3 of State Forest Administration and Management, the term "management of state forests" signifies activities that produce forest products, such as lumber through forestry projects within state forests, including afforestation, cultivating forests, production of 
forest trees, installation of forest administration infrastructure, protection of genetic forestry resources, and so on, and maintaining and increasing the diverse function of forests, such as economic, social, cultural, and environmental functions. The term "administration of state forests" is defined as property administration, such as the conservation, lease, permission for use, exchange, purchase and sale of state forests.

ROK has a long history of Songgye as one type of public participation in forest management. "Songgye" is a traditional social institution for forest management by local residents in the late Chosun Dynasty of Korea (nearly 300 years ago) [35]. Songye has the rules and regulations similar to the contemporary laws of municipal governments. Sanlimgye was organized following the history of Songgye. Toward the end of the 1950s, a total of 21,628 Sanlimyges, consisting of over 2 million members, were established [36] (p. 316). However, the Sanlimyges were not spontaneously formed by villagers in the process of forest rehabilitation. The government encouraged communities to build Sanlimgyes consisting of forest owners and villagers to protect and plant trees, while governmental resources were limited to rehabilitating wholly denuded forest lands. According to Article 4 of the Provisional Forest Protection Act, enacted in 1951, the Minister of the Ministry of Agriculture and Forestry could organize and de-organize Sanlimgyes and require certain activities from Sanlimgyes in the process of monitoring forest management.

The Korea Forest Service (KFS), established in 1967 as a central governmental agency in the forestry sector, administers and manages state forests. ROK forest policies have been implemented according to the National Forest Development Plan (NFDP) established by KFS since 1972. NFDPs present forest policy goals and strategies. KFS implemented strong policies for forest rehabilitation from the 1970s to the 1980s, based on the 1st NFDP (1972-1978), 2nd NFDP (1979-1987) and 3rd NFDP (1988-1997) [37]. At that time, $68 \%$ of total forests in the ROK were privately owned. KFS provided forestland owners with not only seedlings and fertilizers but also technology transfer and tax benefits to encourage them to restore private forests [38]. Since the 1990s, KFS has focused SFM towards harmony between the environment, economy and society. KFS administers and manages state forests following the principles of SFM. In particular, the 4th NFDP (1998-2007) and 5th NFDP (2008-2017) propose forest management through public participation as a crucial agenda. At that time, the conflicts between two interests, forest conservation and urban development emerged. In most conflict cases, civil society consisting of scientists, NGOs and citizens criticized unsound development plans by governments and enterprises and executed conservation movements including campaigns, demonstration, petitions, and so forth [39]. In this context, the policy approach of forest administration has shifted from being supply-centric to demand-centric [40]. KFS investigates citizens' demands and preferences for forests, and establishes and implements forest policies to maximize them.

Since the 1990s, some studies on public participation in forest management have been conducted in the ROK. Several studies indicate that various stakeholders, including enterprises and residents, have the intention of participating in forest management [41-43]. Kim et al. [44] investigated that urban forestry officials recognized the importance of urban forestry partnership between public and private actors. Bae et al. [45] recommended applicable measures of public participation in the Forest Development Plan such as the comment/response procedure, opinion meetings, workshops with the participation of multiple stakeholders, the public notification system, and surveys on public concerns on forests in the case of the ROK. Especially strategies for improving participation by citizens and enterprises have been recommended in forest carbon offset projects [43]. Park and Youn [46] partially examined the legislation relating to urban forests functioned as a framework for urban forest policies at the national and local levels and voluntary agreements as new rules governing the relationships among the actors who were involved in urban forest management. Park and Youn [47] highlighted improvement of forest legislations to enhance public participation in forest carbon management in the ROK comparing with Japanese legislations. However, no study has intensively analyzed the legal framework on public participation in forest management in the ROK. 


\section{Research Design and Method}

This study aimed to analyze the legal opportunities for managing state forests through public participation in the ROK. This paper collected and analyzed policy documents, including national plans, legislative texts, and policy reports on state forest management and public participation during the period from 1998 to 2015, which includes the 4th and the 5th National Forest Development Plan (NFDP) (1998-2017) (Table 2). Based on the contents of the Aarhus Convention, access to forest information, public participation in decision-making, and access to justice in state forests matters were examined. The ROK is not a member country of the Aarhus Convention. However, three environmental rights in the Aarhus Convention can be regarded as crucial conditions despite the non-signature.

Table 2. List of analyzed documents.

\begin{tabular}{cl}
\hline Type of Documents & \multicolumn{1}{c}{ Title of Documents } \\
\hline \multirow{2}{*}{ National plan } & The 4th National Forest Development Plan (NFDP) (1998-2007) \\
& The 5th National Forest Development Plan (NFDP) (2008-2017) \\
& Framework Act on Forestry \\
& State Forest Administration and Management Act \\
& Enforcement Decree of the State Forest Administration and Management Act \\
& Enforcement Rule of the State Forest Administration and Management Act \\
& Creation and Management of Forest Resources Act \\
& Enforcement Decree of the Creation and Management of Forest Resources Act \\
& Enforcement Rule of the Creation and Management of Forest Resources Act \\
\hline Provision & Provision of Conflict Prevention and Resolution by Public Institutions \\
\hline Guideline & Guideline of Forest Products through State Forest Conservation Agreement \\
\hline Instruction & Instruction of State Forest Administration and Management \\
\hline Established Rule & Rules of State Forest Management Plans \\
\hline
\end{tabular}

To investigate state forest conflicts, we analyzed litigation suits related to state forests. We collected 22 litigation cases containing the word "state forest" between 1994 to 2013 from the online legal information system of the Supreme Court of Korea [48]. The online legal information system provides litigations at all types of courts including Administrative, District, High, and Supreme Courts. In principle, decisions of lower courts can be changed by the superior courts. If a case is handled at the District Court and finally moved to the Supreme Court, the online legal information system provides only the final decision of the Supreme Court litigation. However, the online system did not provide all cases of litigations regarding to state forests. Many trials could be canceled while underway, and the conflicts could be resolved prior to a judgment. Although the selected cases are limited, they are a valuable source which presents the status of state forests conflicts. The contents of the litigations were analyzed with a focus on substances and litigants (plaintiffs and defendants). Referring to previous studies $[9,32,33]$, the legal opportunities for public participation were investigated using four scales: information sharing; consultation; collaborative decision-making; and implementation. Information sharing is the first stage of the public participation process [26]. Consultation is conducted with social actors who present their different interests at stake. At the stage of collaborative decision-making and implementation, social actors participate in making decisions on state forest management with public actors and managing state forests through negotiated agreements or contracts.

\section{Results}

Participatory activities by private actors in managing state forests were described using three environmental rights: access to information, public participation in decision-making, and standing in courts. They were interpreted with four dimensions of public participation: information sharing; consultation; collaborative decision-making; and implementation. 


\subsection{Access to Information}

The Official Information Disclosure Act, enacted in 1998, directed public institutions to disclose any information kept and managed by themselves to the public and ensure people's right to know (Article 3). Article 7 requires that public institutions shall decide on the detailed scope of information disclosure and the period, timing, and methods for such disclosure in advance and officially announce the information. Public institutions shall enforce this Act and modify related acts and subordinate statutes to ensure that people's right to request information disclosure is respected (Article 6). Enforcing this Act, KFS as a central forest administration discloses information on forest conditions and forest policies. According to Article 33 of the Creation and Management of Forest Resources Act, KFS has built and administers a forest resource information system to efficiently utilize survey data about forest resources. KFS has provided various information including national forest plans, major policies, forest events and so forth through its internet homepage [49]. The status of the execution of the budget is reported regularly. KFS transfers information on the activities of the advisory committee and hosts presentations for residents and panel discussions regarding state forest management irregularly. KFS established a forest information disclosure system. Within the system, according to Article 10 of the Official Information Disclosure Act, any person who intends to make a request for disclosing information may submit a written request for disclosing information or make an oral request for information disclosure to the governmental forest organization that holds or manages the relevant information. In particular, KFS provides information on recreational forests including the reservation of facilities such as cabins. The persons in charge of information disclosure were appointed by the KFS. Article 3 of the Enforcement Rule of the State Forest Administration and Management Act encourages governments to collect residents' opinions on the process of establishing comprehensive plans for state forests. However, the State Forest Administration and Management Act does not include any articles on the disclosure of information on state forest management plans and policies. There are no related rules or guidelines on public hearings and explanation meetings where information on state forest management can be transferred and shared. The legal framework is not specialized for sharing information on state forest administration and management regularly and continuously. Informing is the most important first step toward citizen participation in the Arnstein's ladder of participation [32] (p. 4). Unstable informing hinders various actors from making decisions on their participation in state forest management.

\subsection{Public Participation in Decision-Making}

KFS established and implemented the committees for state forest management comprising multiple stakeholders. Article 7 of the State Forest Administration and Management Act allows advisory committees on state forest management and administration to be established under the jurisdiction of regional Forest Services. The committees provide advice on the matters concerning the formulation of comprehensive plans for state forests, the analysis and assessment of results of implementation, the designation and cancellation of forest protection areas, the disposal and lease of state forests and so forth. From September 2006 to December 2013, a total of 177 committee meetings were held, and 264 agenda items were addressed at these meetings [50]. The committees comprise multiple experts from governmental agencies, research organizations, civil associations, journalists, enterprises, lawyers, residents and so on, whom ministers of Regional Forest Services appoint (Article 7 of Enforcement Decree of the State Forest Administration and Management Act). Currently, half of the committee members are university professors in the field of forest science, landscape architecture, tourism, wood science and so on, while $8 \%$ of total members are residents. Scientific advice is relatively dominant in concluding decisions on state forest management in the committee. Multiple stakeholders do not have an equal opportunity to work as a member of the advisory committees. Article 3 of the Enforcement Rule of the State Forest Administration and Management Act encourages governments to collect residents' opinions in the process of establishing the comprehensive plans for state forests. However, there are no related rules or guidelines on public hearings and explanation meetings. 
The Provision of Conflict Prevention and Resolution by Public Institutions demands that central administrative agencies establish and implement comprehensive policies and modify related acts to prevent and resolve conflicts (Article 4). Article 11 of the Provision requires public administrative agencies to have the Deliberative Committee for Conflict Management to review matters concerning conflict. KFS established the Deliberative Committee for Conflict Management in September 2007. The committee comprises four members from the public sector and seven members from the private sector. The committee reviews agendas on the implementation of strategies, modification of regulations, evaluation of conflict impacts, and so on. The Committee members with the right of deliberation and resolution can make decisions on arbitration, conciliation, recommendations, and warnings. In principle, public and private actors can make decisions on managing state forest conflicts through the Deliberative Committee for Conflict Management. However, the detailed decisions of the Deliberative Committee for Conflict Management are not disclosed to the public.

Article 15 of the State Forest Administration and Management Act allows, where necessary, for the efficient promotion of forestry projects, development of local communities, increases in residents' income and so on. The Minister of the Korea Forest Service may perform forestry projects jointly with the heads of related central administrative agencies, heads of local governments or heads of organizations. Where the Minister of the Korea Forest Service intends to implement joint forestry projects with joint project implementers, he/she shall conclude an agreement with the relevant joint project implementers. Where necessary for joint forestry projects, the Minister of the Korea Forest Service may implement projects in public forests, private forests and other land adjacent to the state forests subject to the implementation of such projects with the consent of the landowners. In such cases, he/she shall consult with joint project implementers. Until February 2014, a total of 34 joint forestry projects was implemented. Thirteen joint forestry projects aimed at establishing and managing forest recreation facilities responding to the needs of citizens for forest recreation [50]. Here, the need to provide recreational opportunities [51] is recognized through the participatory approach.

Article 11 of the State Forest Administration and Management Act permits, when necessary, for the protection of state forests, the Minister of the Korea Forest Service to conclude an agreement with forestry cooperatives and residents of the relevant areas, schools or organizations comprising forestry technicians and specify certain districts to implement protective activities; this includes the prevention of forest fires, illicit felling, and so on in the specified districts. In such cases, the forest products produced in the relevant state forests may be wholly or partially conceded to such persons without compensation. Forest products that can be conceded include mushrooms, fruits, herbs, sap and so on (Article 9 (2) of the Enforcement Rule of the State Forest Administration and Management Act). The protection agreements shall be up to five years; however, they may be extended by up to five years if necessary. When a person who has concluded protection agreements violates the matters of protection agreements or is negligent in protective activities, the Minister of the Korea Forest Service may cancel such protection agreements and notify the parties to such protection agreements of the cancellation thereof. The protection agreements contribute to increasing the livelihood of the parties. For example, for the last three years the Hongcheon National Forest Station has concluded the State Forest Protection Agreements with approximately one thousand residents and conceded 1 billion Korean Won (US\$0.86 million) of forest products until July 2013 [52].

\subsection{Standing in Courts}

Article 27 of the Constitution of the ROK indicates that all citizens shall have the right to be tried in conformity with the Act by judges qualified under the Constitution and the Act. The Framework Act on Environmental Policy excludes the article on the right of standing in courts regarding environmental conflicts. Forest-related acts also exclude the article on the right of standing in courts regarding forest conflicts. Forest conflicts are currently treated as civil and administrative cases under the Civil Procedure Act and the Administrative Litigation Act. 
The conflicts between public and private sectors in managing state forests occasionally lead to litigation. The Table 3 lists the 22 selected litigation cases regarding state forests from the online legal information system. The most cases ( 15 cases, $68 \%$ ) include decisions by the Supreme Court. It means that most cases are finally judged by the Supreme Court with the strongest binding authority among courts. In most of the cases (19 cases, $86 \%$ ), individuals as plaintiffs sued public agencies including cities, districts, counties, national forest stations, public corporations and so on. They demanded redress for public administration. Seven civil litigations were related to ill-gotten gains in leasing state forests. According to Article 21 of the State Forest Administration and Management Act, the Minister of KFS may permit the use of permanent state forests or lease non-permanent state forests. The Minister shall collect lease charges every year according to the rates and calculating methods prescribed by Presidential Decree (Article 23). In the litigation cases, the ROK required higher prices for lease charges when the land priced increase on the date of the lease contract extensions. The ROK imposed the refund of ill-gotten gains from the leasers, when the lease costs were accounted for by the data of old prices of the forest lands. Against the ROK request, enterprises criticized the calculating methods in leasing state forests. They insisted on holding the non-changed prices regardless of the change in forest land prices over time. In four litigation suits, public agencies levied indemnity on the use of state forests as national assets without legal permission. Individuals and enterprises criticized the overestimation of the amount of indemnity and the lack of prior notification of the target of indemnity imposed by public agencies. They requested revocation of the disposition of the indemnity imposition. Here, they invoked their right of standing by filing the litigations. In four litigation suits, governmental agencies sued individuals and enterprises due to the registration of ownership to standing trees and forest lands. Individuals and enterprises as defendants argued their rights to standing trees and forest lands. They also invoked their right of standing by responding to governmental legal requests.

Table 3. List of litigation suits related to state forests.

\begin{tabular}{|c|c|c|c|c|c|c|}
\hline No. & $\begin{array}{l}\text { Judgment Date } \\
\text { (dd/mm/year) }\end{array}$ & Type of Trials & $\begin{array}{l}\text { Type of } \\
\text { Court }\end{array}$ & Plaintiff & Defendant & Substance \\
\hline 1 & 22 March 1994 & Administrative & Supreme & Individual & District & Indemnity \\
\hline 3 & 14 October 1994 & Tax & Supreme & Enterprise & County & Acquisition tax \\
\hline 6 & 8 November 1996 & Civil & Supreme & Enterprise & Republic of Korea & Ill-gotten gains \\
\hline 7 & 14 March 1997 & Civil & Supreme & Individual & Republic of Korea & $\begin{array}{c}\text { Registration of } \\
\text { ownership transfer }\end{array}$ \\
\hline 8 & 17 September 1999 & Civil & District & Individual & Republic of Korea & Compensation for damages \\
\hline 11 & 26 May 2000 & Civil & Supreme & Enterprise & Republic of Korea & Ill-gotten gains \\
\hline 12 & 27 September 2002 & Civil & Supreme & Republic of Korea & Enterprise & $\begin{array}{l}\text { Registration of state } \\
\text { ownership transfer }\end{array}$ \\
\hline 13 & 16 October 2003 & Administrative & High & Individual & $\begin{array}{l}\text { Public Committee } \\
\text { on Land } \\
\text { Expropriation }\end{array}$ & Land expropriation \\
\hline 14 & 28 May 2004 & Civil & District & Enterprise & Republic of Korea & Ill-gotten gains \\
\hline 15 & 8 October 2004 & Administrative & Administrative & Individual & $\begin{array}{c}\text { Ministry of } \\
\text { National Defense }\end{array}$ & $\begin{array}{l}\text { Approval of the plan on } \\
\text { military installation }\end{array}$ \\
\hline 16 & 8 October 2004 & Civil & High & City & Foundation & $\begin{array}{l}\text { Recapture of property by } \\
\text { cancellation of commission } \\
\text { management contract }\end{array}$ \\
\hline
\end{tabular}


Table 3. Cont.

\begin{tabular}{ccccccc}
\hline No. & $\begin{array}{c}\text { Judgment Date } \\
\text { (dd/mm/year) }\end{array}$ & Type of Trials & $\begin{array}{c}\text { Type of } \\
\text { Court }\end{array}$ & Plaintiff & Defendant & Substance \\
\hline 18 & 13 October 2009 & Administrative & Administrative & Enterprise & $\begin{array}{c}\text { Korea Asset } \\
\text { Management } \\
\text { corporation }\end{array}$ & Indemnity \\
\hline 19 & 10 December 2009 & Civil & Supreme & Republic of Korea & Enterprise & $\begin{array}{c}\text { Registration of } \\
\text { ownership transfer }\end{array}$ \\
\hline 20 & 9 June 2012 & Civil & High & Enterprise & Republic of Korea & Ill-gotten gains \\
\hline 21 & 14 March 2013 & Civil & Supreme & Enterprise & Republic of Korea & Ill-gotten gains \\
\hline 22 & 28 June 2013 & Civil & Supreme & Enterprise & County & Ill-gotten gains \\
\hline
\end{tabular}

\section{Discussion and Conclusions}

Public participation in state forest management is a means of improving multiple-use forestry through balanced integration of the various social demands toward state forests [11] (p. 14). This paper examined the legal opportunities for social actors to participate in the process of managing state forests in the ROK. It investigated how three environmental rights were guaranteed legally and institutionally at the level of participation in managing state forests, linking with three key dimensions of forest governance: transparency, participation, and accountability.

In principle, the right to know official information is guaranteed according to the Official Information Disclosure Act in the ROK. However, under the Official Information Disclosure Act, any forest-related act does not require access to information on the management and administration of state forests. Irregularly, some related information has been transferred through the mass media without the rule of disclosing forest information. This means that the current legal framework does not guarantee informing as the third rung of Arnstein's ladder of citizen participation [32] in state forest management in the ROK. Unstable and unclear information-sharing can threaten transparency of the management and administration of state forests. Forest authorities should give clear and timely notice of all proposed policies, programs, laws and projects for good forest outcomes [27]. It may be a reason for the lack of public participation in forest management that stakeholders do not have the necessary information to understand the issue of state forest management [11]. Information sharing in an appropriate way can induce potential participants to be forthcoming. Information sharing and communication are means to increase awareness of the public about various issues of state forest management and administration [11]. Recently internet, especially Twitter, can function as an effective information delivery channel and a communication arena where socialization-oriented conservation can be mutually exchanged [53]. For enhancing the transparency of state forest management and administration, clear rules on accessing to and sharing information on management and administration of state forests are needed at the national and local levels.

The right to public comment is related to the stages of public participation: consultation, collaborative decision-making, and implementation. Multiple stakeholders can present their comments to state forest policies and programs through the advisory committees and public hearings. These activities are one type of direct participation [23]. The advisory committees and public hearings provide opportunities for debates among various interest groups [27]. The State Forest Administration and Management Act guarantees the establishment and implementation of advisory committees for state forest management. Committee members discuss and review various topics on state forest management. For example, the issue of invasive alien species is underlined in forest management. Recently in Europe a new regulation on the prevention and management of the introduction and spread of invasive alien species was adopted [54]. Robinia pseudoacacia is a worrying alien species in Europe [54] and also in the ROK [55]. Robinia pseudoacacia was introduced from North America in the 19th Century and was heavily used in the 1960s for reforestation after the Korean War in the ROK. It has invaded other vegetation beyond originally planted zones. Therefore, preventing and managing the introduction and spread of Robinia pseudoacacia as an invasive alien species can be discussed at 
the advisory committee meetings and public hearings on state forest management. However, the State Forest Administration and Management Act does not require public hearings. Comparing with United States, the Section 14 of National Forest Management Act (1976) requires that the United States Forest Service establish procedures, including public hearings where appropriate, to give the federal, state, and local governments and the public an opportunity to comment upon the formulation of standards, criteria, and guidelines applicable to Forest Service programs. In the ROK the private actor legally can make decisions on state forest management collaboratively with public actors through the Deliberative Committee for Conflict Management based on the Provision of Conflict Prevention and Resolution.

However, the mode of collaborative decision-making through the deliberative committee was not clearly identified in the legislation regarding state forest management. The State Forest Administration and Management Act allows negotiated agreements to be concluded between forest administrative agencies and residents or organizations for the protection of state forests. The agreements require the accountability of social actors in using and protecting state forests. Based on the agreements, social actors participate in implementing state forest management programs and projects. Public and private actors share the costs and benefits of state forest management through the negotiated agreements. This direct participation by social actors in state forest management and administration can contribute to enhancing the social sustainability of forest management [11] (p. 7). Therefore the current legal framework supports partnership between public and private actors as the sixth rung of Arnstein's ladder of citizen participation [32] in state forest management in the ROK.

The right of standing in courts is achieved through litigation as a means to solve conflicts. Individuals and enterprises play a role as defendants and plaintiffs in the ROK state forest litigations. In the process of litigation, individuals and enterprises reveal their arguments and rights to trees and forest lands. They exercise their authority to demand redress for wrongdoings by governmental agencies [31]. The right of standing reflecting accountability implies that some actors have the right to hold other actors to judge whether they have fulfilled their responsibilities on state forest management in light of the standards [30] (p. 29). To solve conflicts on state forest management, the right of standing in courts should be guaranteed through a legal framework. Currently, the ROK has no specific acts regarding forest litigation. Instead, other acts such as the Civil Procedure Act and the Administrative Litigation Act are used. To guarantee the right of standing in court in the field of state forest management, clear articles on forest litigations should be included in the State Forest Administration and Management Act. The article on forest litigation can be a basis for establishing and implementing forest conflict management policies. In addition, it would be very helpful for effective application of the litigation system for a manual or guideline of filing forest litigations to be established and made open to the public. On the other hand, instead of litigation, alternative dispute resolution (ADR) can be applied to mitigate forest conflicts. ADR is a set of practices that aims to permit legal disputes to be resolved outside the courts for the benefit of all disputants [56]. It includes arbitration, mediation, conciliation, and negotiation [56]. Above all, ADR can reduce the time and cost of conventional litigations. The United States Forest Service used ADR process to resolve forest plan appeals [57]. KFS also can organize and manage the Council for Conflict Resolution as an ADR, if necessary, based on Article 16 of the Provision of Conflict Prevention and Resolution by Public Institutions. The Council can handle land use conflicts centered on resource extraction and conservation conflicts between stakeholders over forest usage [58]. The detailed guideline and manual are required for implementing the Council for Conflict Resolution effectively and efficiently.

The research results indicate meaningful lessons for designing a legal framework to promote participatory forest management. However, this research has some limitations. We focused on the legal system on the management and administration of state forests through document analysis. We could not examine how well the legal institution functions in practice. In future study, local case studies should be conducted to understand the phenomenon of public participation in state forest management. Despite the challenges, the research findings do contribute to extending our understanding of the legal 
system of public participation in managing state forests. Based on these findings, further studies on participatory forest management can be developed.

Acknowledgments: This study was conducted with the support of a "Forest Science \& Technology Projects" grant (Project No. S211315L020140) provided by the Korea Forest Service. This paper was supported by the KU Research Professor Program of Konkuk University, Republic of Korea.

Author Contributions: Mi Sun Park and Hyowon Lee contributed equally to all sections of this paper. Both authors read and approved the final manuscript.

Conflicts of Interest: The authors declare no conflict of interest.

\section{Abbreviations}

The following abbreviations are used in this manuscript:

\begin{tabular}{|c|c|}
\hline KFS & Korea Forest Service \\
\hline NFDP & National Forest Development Plan \\
\hline ROK & Republic of Korea \\
\hline REDD+ & $\begin{array}{l}\text { Reducing emissions from deforestation and forest degradation and enhancing } \\
\text { conservation, sustainable management of forests and forest carbon stocks }\end{array}$ \\
\hline & Sustainable Forest Management \\
\hline NCED & United Nations Conference on Environment and Development \\
\hline
\end{tabular}

\section{References}

1. Rio Declaration on Environment and Development. Available online: http://www.unep.org/documents. multilingual / default.asp?documentid=78\&articleid=1163 (accessed on 8 January 2016).

2. Agenda 21. Available online: http://www.unep.org/documents.multilingual/default.asp?documentid=52 (accessed on 8 January 2016).

3. The Convention on Access to Information, Public Participation in Decision-making and Access to Justice in Environmental Matters (Aarhus Convention). Available online: http://www.unece.org/env/ pp/treatytext.html (accessed on 8 January 2016).

4. Palerm, J.R. Public participation in environmental decision-making: Examining the Aarhus Convention. Environ. Assess. Policy Manag. 1999, 1, 229-244. [CrossRef]

5. Kravchenko, S. The Aarhus Convention and innovations in compliance with multilateral environmental agreements. Colorado J. Int. Environ. Law Policy 2007, 18, 1-50.

6. Mason, M. Information disclosure and environmental rights: The Aarhus Convention. Glob. Environ. Politics 2010, 10, 10-31. [CrossRef]

7. Kangas, A.; Saarinen, N.; Saarikoski, H.; Leskinen, L.A.; Hujala, T.; Tikkanen, J. Stakeholder perspectives about proper participation for Regional Forest Programmes in Finland. For. Policy Econ. 2010, 12, 213-222. [CrossRef]

8. Cantiani, M.G. Forest planning and public participation: A possible methodological approach. iForest 2012, 5, 72-82. [CrossRef]

9. Bruna-Garcia, X.; Marey-Perez, M.F. Public participation: A need of forest planning. iForest 2014, 7, 216-226. [CrossRef]

10. Forest Principles. Available online: http://www.un.org/documents/ga/conf151/aconf15126-3annex3.htm (accessed on 8 January 2016).

11. MCPFE (Ministerial Conference on the Protection of Forests in Europe). Public Participation in Forestry in Europe and North America; MCPFE: Vienna, Austria, 2002; pp. 4-14. Available online: http://www. foresteurope.org/documentos/public_participation_in_forestry.pdf (accessed on 8 January 2016).

12. Pagdee, A.; Kim, Y.S.; Daugherty, P.J. What makes community forest management successful: A meta-study from community forests throughout the world. Soc. Nat. Resour. 2006, 19, 33-52. [CrossRef]

13. Ellis, E.A.; Porter-Bolland, L. Is community-based forest management more effective than protected areas?: A comparison of land use/land cover change in two neighboring study areas of the Central Yucatan Peninsula, Mexico. For. Ecol. Manag. 2008, 256, 1971-1983. [CrossRef] 
14. Behera, B.; Engel, S. Institutional analysis of evolution of joint forest management in India: A new institutional economics approach. For. Policy Econ. 2006, 8, 350-362. [CrossRef]

15. Sundar, N.; Jeffery, R.; Thin, N. Branching out: Joint Forest Management in India; Oxford University Press: New Delhi, India, 2001.

16. Blomley, T.; Ramadhani, H. Going to Scale with Participatory Forest Management: Early Lessons from Tanzania. Int. For. Rev. 2006, 8, 93-100. [CrossRef]

17. Inoue, M. Participatory forest management. In Rainforest Ecosystems of East Kalimantan: El Niño, Drought, Fire and Human Impacts; Guhardja, E., Farawi, M., Sutisna, M., Mori, T., Ohta, S., Eds.; Springer Science \& Business Media: Tokyo, Japan, 2000; Volume 140, pp. 299-307.

18. Mustalahti, I.; Lund, J.F. Where and how can participatory forest management succeed? Learning from Tanzania, Mozambique, and Laos. Soc. Nat. Resour. 2009, 23, 31-44. [CrossRef]

19. Kangas, J. An approach to public participation in strategic forest management planning. For. Ecol. Manag. 1994, 70, 75-88. [CrossRef]

20. Lynch, O.J.; Talbott, K. Balancing Acts: Community-Based Forest Management and National Law in Asia and the Pacific; World Resources Institute: Washington, DC, USA, 1995.

21. White, A.; Martin, A. Who Owns the World's Forests? Forest Tenure and Public Forests in Transition; Forest Trends: Washington, DC, USA, 2002.

22. Beckley, T.M.; Parkins, J.R.; Sheppard, S. Public Participation in Sustainable Forest Management: A Reference Guide; Sustainable Forest Management Network: Edmonton, Canada, 2006; Available online: http:/ / cfs.nrcan.gc.ca/pubwarehouse/pdfs/26206.pdf (accessed on 8 January 2016).

23. Cox, R. Environmental Communication and the Public Sphere, 3rd ed.; SAGE: Los Angels, CA, USA, 2013.

24. Krott, M. Forest Policy Analysis; Springer: Dordrecht, The Netherlands, 2010; pp. 265-288.

25. Mahanty, S.; McDermott, C.L. How does 'Free, Prior and Informed Consent' (FPIC) impact social equity? Lessons from mining and forestry and their implications for REDD+. Land Use Policy 2013, 35, 406-416. [CrossRef]

26. Paletto, A.; Cantiani, M.G.; De Meo, I. Public participation in Forest Landscape Management Planning (FLMP) in Italy. J. Sustain. For. 2015, 34, 465-482. [CrossRef]

27. Secco, L.; Da Re, R.; Pettenella, D.M.; Gatto, P. Why and how to measure forest governance at local level: A set of indicators. For. Policy Econ. 2014, 49, 57-71. [CrossRef]

28. Malmsheimer, R.W.; Keele, D.; Floyd, D.W. National forest litigation in the US courts of appeals. J. For. 2004, $102,20-25$.

29. THE PROGRAM ON FORESTS (PROFOR); FAO. Framework for Assessing and Monitoring Forest Governance; PROFOR and FAO: Rome, Italy, 2011.

30. Grant, R.W.; Keohane, R.O. Accountability and abuses of power in world politics. Am. Political Sci. Rev. 2005, 99, 29-43. [CrossRef]

31. Jedd, T.; Bixler, R.P. Accountability in Networked Governance: Learning from a case of landscape-scale forest conservation. Environ. Policy Gov. 2015, 25, 172-187. [CrossRef]

32. Arnstein, S.R. A ladder of citizen participation. J. Am. Plan. 1969, 35, 216-224. [CrossRef]

33. Maier, C.; Lindner, T.; Winkel, G. Stakeholders' perceptions of participation in forest policy: A case study from Baden-Württemberg. Land Use Policy 2014, 39, 166-176. [CrossRef]

34. Korea Forest Service. 2015 Statistical Yearbook of Forestry; Korea Forest Service: Daejeon, Korea, 2015.

35. Chun, Y.W.; Tak, K.I. Songgye, a traditional knowledge system for sustainable forest management in Choson Dynasty of Korea. For. Ecol. Manag. 2009, 257, 2022-2026. [CrossRef]

36. Choi, B. The developments and character of setting up the forestry mutual-aid society in 1945-1960s. J. Hist. Stud. 2008, 90, 291-336. (In Korean)

37. Park, M.; Lee, H. Forest policy and law for sustainability within the Korean peninsula. Sustainability 2014, 6, 5162-5186. [CrossRef]

38. Korea Forest Service. The 50-year History of Korea Forest Policy; Korea Forest Service: Seoul, Korea, 1997. (In Korean)

39. Park. Media Discourse in Forest Communication: The Issue of Forest Conservation in the Korean and Global Media; Cuvillier: Goettingen, Germany, 2009. 
40. Lee, C.W.; Park, H.B.; Lim, Y.J.; Jeon, E.S.; Kim, J.H.; Park, H.S.; Lim, T.K. A Study on the Customer Management and Citizen Participation for the Development of Forest Administration; Korea Forest Service: Daejeon, Korea, 2005; pp. 14-21. (In Korean)

41. Park, K.S.; Lee, S.Y.; Choi, S.I.; Song, Y.G.; An, K.W. Strategies for Promoting National Forest Management through Participation by Multiple Actors; Korea Forest Research Institute: Seoul, Korea, 2010; pp. 65-79. (In Korean)

42. Gallup Korea. Survey Report of Awareness to Forest Management Investment by Korean Forest Owners and Enterprises; Gallup Korea: Seoul, Korea, 2011; pp. 75-103. (In Korean)

43. Forest for Life. Development of Manuals for Designing and Implementing Forest Carbon Offset Projects through Participation by Citizens and Enterprises; Korea Forest Service: Daejeon, Korea, 2009; pp. 73-82. (In Korean)

44. Kim, J.H.; Tae, Y.L.; Chang, C.Y.; Kim, K.M. Study on current status and direction of environmental governance around urban forest in Korea: With a focus on the recognition of local government officials. J. Korean For. Soc. 2010, 99, 580-589. (In Korean)

45. Bae, J.S.; Yoo, Y.M.; Song, Y.G.; Park, K.S. A study on the applicable public participation in national forest plan system. J. Korean For. Soc. 2004, 93, 75-85. (In Korean)

46. Park, M.; Youn, Y. Development of urban forest policy-making toward governance in the Republic of Korea. Urban For. Urban Green. 2013, 12, 273-281. [CrossRef]

47. Park, M.; Youn, Y. Legal institutions for enhancing and protecting forests as a carbon sink in Japan and the Republic of Korea. For. Sci. Technol. 2013, 9, 72-80.

48. Legal information system by Supreme Court of Korea. Available online: http://glaw.scourt.go.kr (accessed on 7 January 2016). (In Korean)

49. Korea Forest Service Homepage. Available online: http://english.forest.go.kr (accessed on 12 April 2016).

50. Korea Forest Service. Source Book of State Forest Administration; Korea Forest Service: Daejeon, Korea, 2014; pp. 5, 42-48, 92-95. (In Korean)

51. Tak, K.; Chun, Y.; Wood, P.M. The South Korean forest dilemma. Int. For. Rev. 2007, 9, 548-557. [CrossRef]

52. Lim, J.S. Concluding the State Forest Protection Agreements between Hongcheon National Forest Station and Yasidae 2 Ri. Hongcheon News (16 July 2013). Available online: http:/ /www.namdonews.com/blog2/ blogOpenView.html?idxno=602900 (accessed on 7 January 2016). (In Korean)

53. Cho, S.E.; Park, H.W. Government organizations' innovative use of the Internet: The case of the Twitter activity of South Korea's Ministry for Food, Agriculture, Forestry and Fisheries. Scientometrics 2011, 90, 9-23. [CrossRef]

54. Sitzia, T.; Campagnaro, T.; Kowarik, I.; Trentanovi, G. Using forest management to control invasive alien species: Helping implement the new European regulation on invasive alien species. Biol. Invasions 2016, 18, 1-7. [CrossRef]

55. Lee, C.S.; Cho, H.J.; Yi, H. Stand dynamics of introduced black locust (Robinia pseudoacacia L.) plantation under different disturbance regimes in Korea. For. Ecol. Manag. 2004, 189, 281-293. [CrossRef]

56. Lieberman, J.K.; Henry, J.F. Lessons from the Alternative Dispute Resolution Movement. Univ. Chicago Law Rev. 1986, 53, 424-439. [CrossRef]

57. Manring, N.J. Alternative dispute resolution and organizational incentives in the US Forest Service. Soc. Nat. Resour. 1998, 11, 67-80. [CrossRef]

58. Gritten, D.; Mola-Yudego, B.; Delgado-Matas, C.; Kortelainen, J. A quantitative review of the representation of forest conflicts across the world: Resource periphery and emerging patterns. For. Policy Econ. 2013, 33, 11-20. [CrossRef]

(C) 2016 by the authors; licensee MDPI, Basel, Switzerland. This article is an open access article distributed under the terms and conditions of the Creative Commons Attribution (CC-BY) license (http://creativecommons.org/licenses/by/4.0/). 